\title{
Thermal and petrophysical characterization of the lithospheric mantle along the northeastern Iberia geo-transect
}

\author{
Alberto Carballo, Manel Fernandez, Montserrat Torne, Ivone Jiménez-Munt, and Antonio Villaseñor \\ Group of Dynamics of the Lithosphere, Institute of Earth Sciences Jaume Almera, ICTJA - CSIC, Lluis Sole i Sabaris s/n, \\ 08028 Barcelona, Spain. acarballo@ictja.csic.es
}

We present a new model on the present-day lithospheric structure along a $1100 \mathrm{~km}$ transect crossing the NE-Iberian Peninsula, the Western Mediterranean basin and the Algeria margin and ends at the Tell-Atlas Mountains. The modeling is based on an integrated geophysical-petrological methodology combining elevation, gravity, geoid, surface heat flow, seismic and geochemical data. Unlike previous models proposed for the region where the density of the lithospheric mantle is only temperature-dependent, the applied methodology allows inferring seismic velocities and density in the mantle down to $410 \mathrm{~km}$ depth from its chemical composition through self-consistent thermodynamic calculations. We have considered five lithospheric mantle compositions including predominantly average Phanerozoic and lherzolitic Proterozoic in the continental mainland, and more fertile PUM (primitive upper mantle) compositions in the Western Mediterranean basin. Mantle petrology affects the resulting density distribution and LAB (lithosphere-asthenosphere boundary) geometry and allows a direct comparison with tomography models and seismic data. Measured low Pn velocities in the Western Mediterranean basin can be explained by either serpentinization and/or seismic anisotropy and only partly by transient thermal effects. The obtained lithospheric structure is compatible with $\mathrm{P}$ - and S-wave tomography models. 